\title{
Exploring the factors associated with coronaphobia among physicians during the COVID-19 outbreak in Egypt
}

\author{
Mohamed Abdelghani ${ }^{1,2}$, Mervat S. Hassan ${ }^{1}$, Hayam M. Elgohary ${ }^{1 *}$ (D) and Eman Fouad ${ }^{1}$
}

\begin{abstract}
Background: Coronaphobia refers to intensified and persistent fears of contracting COVID-19 virus infection. This study aimed to evaluate the newly termed phenomenon, coronaphobia, and address its associated correlates among Egyptian physicians during the outbreak. A cross-sectional study, including a total of 426 Egyptian physicians working during COVID-19 outbreak, was conducted between March 1st and May 1st, 2020. The Fear of COVID-19 Scale (FCV-19S) and Hospital Anxiety and Depression Scale (HADS) were utilized for assessment of coronaphobia, and comorbid anxiety and depressive symptoms among physicians, respectively during the outbreak.

Results: Moderate-to-severe symptoms of anxiety and depression were reported by $28 \%$ and $30 \%$ of physicians, respectively. Physicians experiencing higher levels of coronaphobia were more likely to be females, nonsmokers, having death wishes and/or self-harming thoughts, receiving insufficient training, dissatisfied with their personal protective equipment (PPE), and had colleagues infected with COVID-19 virus infection. Coronaphobia was positively correlated with anxiety $(r=0.59, P<0.001)$ and depressive symptoms $(r=0.47, P<0.001)$.

Conclusions: Egyptian physicians experienced higher levels of coronaphobia, anxiety, and depressive symptoms during the COVID-19 outbreak. Yet, frontline physicians did not differ from their second-line counterparts regarding the aforementioned symptoms. Routine mental and physical assessment measures of medical staff should be implemented.
\end{abstract}

Keywords: Coronaphobia, COVID-19 outbreak, Physicians, Egypt

\section{Background}

In December 2019, the coronavirus disease 2019 (COVID-19) outbreak caused by severe acute respiratory syndrome coronavirus 2 (SARS-Cov-2) had arisen in Wuhan, China [1]. World Health Organization announced the COVID-19 outbreak, as a global pandemic in March 2020. Yet, there is a lack of definite information about the nature and course of this novel, rapidly spreading virus [2]. The COVID-19 pandemic itself, subsequent lockdown, social life disturbances, and

\footnotetext{
* Correspondence: dr.hayamelgohary@yahoo.com

'Psychiatry Department, Faculty of Medicine, Zagazig University, Zagazig, Egypt

Full list of author information is available at the end of the article
}

financial problems are negatively affecting mental health and well-being [3]. Indeed, there is increasing attention to the psychological impact of the COVID-19 pandemic at the research [4], on general populations [5], as well as healthcare professionals [6].

The medical staff are the frontline health care workers who are facing excess load during the pandemic [2]. Excessive worries of COVID-19 were evident among the medical staff [7]. Coronaphobia, a novel term in the psychiatric literature, was reported in previous research worldwide, and likely related to the novelty of the virus and uncertainties about the consequences of the COVID19 pandemic [8]. Coronaphobia refers to excessive fears and worries of being infected by coronavirus [9]. For the 
health care workers, direct contact with COVID-19 patients, limited numbers of protective equipment, and denying of COVID-19 virus infection by some patients are factors that increase these fears among medical staff about being infected with the virus and transmitting the infection to their families.

Moreover, the psychological responses to previous epidemics and pandemics suggest that different psychological vulnerability factors may play a role. The intolerance of uncertainty, perceived vulnerability to disease, anxiety proneness, lack of information, and getting misinformation from popular media headlines may, collectively or separately, play a substantial role in increasing health-related fears and phobias and shaping coronophobia [10]. This prolonged struggle may lead to anxiety and depression among the health care workers, especially physicians [11].

To our knowledge, studies examining and focusing on coronaphobia among medical staff during the COVID19 outbreak in Egypt are scarce, if any. This study aimed to explore the newly termed phenomenon, coronaphobia, and identify its associated correlates among physicians during their battle against the COVID-19 pandemic in Egypt.

\section{Methods}

The cross-sectional survey study was conducted from March 1st to May 1st, 2020. A total of 444 physicians, working during the COVID-19 outbreak in general hospitals in Sharkia Province, were included in the study. The sample size was calculated using Epi Info 6.0 , at $80 \%$ power of the study, $95 \%$ confidence level [12]. In Sharkia Province, around 7760 physicians from various specialties are currently working in general hospitals [13]. As the local health authorities recommended social distancing, and owing to lockdown restrictions, the authors had designed a Google form including a questionnaire to collect sociodemographic and clinical data of participants, Fear of COVID-19 and Hospital Anxiety and Depression Scales for assessment of fear of COVID-19 levels and depression and anxiety respectively, and sent the corresponding link by Whats app. messages through telephone to the selected participants.

The physicians were chosen via the systematic random method. The largest three governmental general hospitals in Sharkia Province were identified where a random sample of physicians from each hospital was selected. By using physician official registry in the medical syndicate of Sharkia Province, name lists (files) of physicians of all specialties and all titles (residents, specialists, and consultants) in the records of each of the defined three hospitals were identified and numbered, then the authors randomly selected one physician based on a system of intervals (every fixed number), and the Google form was sent to each physician via Whats app. message.

During the data collection, eighteen physicians (4.1\%) refused to complete the study. After excluding the incomplete responses, the final sample size included in the study was 426 physicians.

All participants were requested to complete the following measures:

A questionnaire including a semistructured checklist designed to collect relevant demographic and clinical data, included close-ended questions with dichotomous responses, either yes or no, investigating the lifetime history of mental illness namely depression, anxiety disorders, and self-harm thoughts and behaviors.

\section{Fear of COVID-19 Scale (FCV-19S)}

This 7-item self-rating tool was utilized for assessing the severity of fears and apprehensions of contracting COVID-19 virus infection (coronaphobia). This scale entails 7 questions answered as "strongly disagree," "disagree," "neither agree nor disagree," "agree," and "strongly agree" with scores from 1 to 5 for each. The higher the score, the greater the level of coronaphobia. An Arabic version of this scale, examined for its reliability and validity, was used in this study $[8,14,15]$.

\section{The Hospital Anxiety and Depression Scale (HADS)}

This 14-item self-rating scale was used for screening the anxiety and depressive symptoms among the participants [16]. This scale included seven questions asking about depressive symptoms, and the other 7 asking for anxiety symptoms with a score of each question from 0 to 3 . The overall score in each subscale ranged from 0 to 21 . Total scores from 0 to 7 considered normal (non-cases), while scores from 8 to 10 were considered borderline (mild cases), and those above 11 were considered valid cases. An Arabic validated version of this scale was used in this study [17].

The data, in this study, were collected and analyzed using the Statistical Package for the Social Sciences (SPSS, Inc) software version 20.0 (Chicago IL, USA) [18]. Qualitative variables were described by frequency distributions, while quantitative variables were described by the means and standard deviations. The chi-squared test was used to compare the proportions of categorical data, and the independent sample $t$ test was used to compare the means of two groups. To assess the relationship between two variables with a linear relationship, the Pearson correlation coefficient was used. All results were considered statistically significant when their significant probability was less than $5 \%(P<0.05)$. 


\section{Results}

This study included a total of 426 Egyptian physicians who were working in general hospitals in Sharkia Province, $282(66.2 \%)$ females, 152 (35.7\%) residents, 139 (32.6\%) working in private clinics or hospitals besides their governmental work, and 38 (8.9\%) smokers. The means of age, daily working hours, and weekly working days were $34.57 \pm 6.5$ years, $8.15 \pm$ $3.89 \mathrm{~h}$, and $4.52 \pm 1.48$ days, respectively. Frontline physicians, who treated isolated patients diagnosed with COVID-19 virus infection, represented $15.5 \%$ of the physicians $(n=66)$, as shown in Table 1 .

Of note, $73 \%(n=310)$ and $84 \%(n=358)$ of physicians reported receiving insufficient training related to pandemic and dissatisfaction with the hospital's personal protective equipment (PPE), respectively. Regarding the psychiatric symptoms, death wishes and/or self-harming thoughts, moderate-to-severe anxiety, and depressive symptoms were reported by $10 \%, 28 \%$, and $30 \%$ of physicians, respectively. Female physicians, compared with their male counterparts, reported higher levels of fear of COVID-19 virus infection (coronaphobia) in six out of the seven items, as well as the overall score of the FCV19 Scale, as shown in Fig. 1.

Table 1 illustrated the relationship between the demographic and clinical variables, and the mean score of coronaphobia (measured by the Fear of COVID-19 Scale). Physicians with higher levels of coronaphobia were more likely to be females $(20.89 \pm 4.91$ vs $18.52 \pm 4.97, P<$ 0.001). According to the recently adopted cut-off point for FCV-19S, it was found that the prevalence of coronaphobia among the selected physicians was $75.4 \%$ ( $n=$ $321)$, nonsmoker $(20.26 \pm 5.04$ vs $18.39 \pm 4.87, P=$ $0.03)$, having death wishes and/or self-harming thoughts $(21.95 \pm 5.33$ vs $19.88 \pm 4.98, P=0.011)$, receiving insufficient training related to the pandemic $(20.54 \pm 5.08$ vs $18.89 \pm 4.79, P=0.003)$, dissatisfied with the hospital PPE $(20.51 \pm 5.0$ vs $17.90 \pm 4.78, P<0.001)$, and having a history of colleagues who were affected with COVID19 infection $(20.66 \pm 4.82$ vs $19.96 \pm 5.19, P=0.04)$, nonsmoker $(20.26 \pm 5.04$ vs $18.39 \pm 4.87, P=0.03)$. Similarly, coronaphobia was found to be positively correlated with the mean scores of both symptoms of anxiety $(r=0.59, P<0.001)$ and depressive symptoms $(r=0.47$, $P<0.001$ ), as illustrated in Table 2.

Frontline physicians, compared with second-line physicians, were more likely to be non-married (39.4\% vs. $26.9 \%, P=0.04)$, residents $(46 \%$ vs $33.6 \%$, $P=0.037)$, working more than $8 \mathrm{~h}$ /daily $(43.9 \%$ vs $24.7 \%, P=0.001)$, received sufficient training related to the pandemic $(37.9 \%$ vs $25.3 \%, P=0.035)$, and have a history of medical colleague affection with COVID-19 infection (69.7\% vs $39.2 \%, P<0.001)$, as illustrated in Table 3.

\section{Discussion}

COVID-19 virus infection does not only affect physical health but also has an impact on the mental health especially of health care providers, who are on the front lines, as they are fighting their global longdrawn battle against COVID-19 [19]. Coronaphobia is a newly emerging phenomenon specifically generated to define excessive fears and worries of contracting COVID-19 virus infection. It has recently been replicated in the research of the mental health burden of the COVID-19 pandemic [10]. The main finding of this study is that the physician, in Egypt, experienced higher levels of coronaphobia during the COVID-19 pandemic. In line with this finding, numerous studies documented intensive and persistent fears and worries not only among physicians but also other health care providers including nurses, technicians, and health workers during the COVID-19 pandemic [2, 7]. The excess fear might be related to the initially insufficient understanding of the virus, the lack of prevention and control knowledge, the shortage and improper use of medical protective equipment, and the exposure to critical life events as the death of patients [20]. Also, as claimed by some of the health care providers, there was the fear of the possibility of the virus transmission to their families or close friends [21]. These concerns would lead the working physicians to isolate themselves from their family members, modify or even change their lifestyle routines, and limit their social connectedness which resulted in psychological pressure, feelings of loneliness and helplessness, and despair [22].

Work overload, burnout, and stress symptoms during the COVID-19 pandemic would make physicians more prone to developing psychiatric disorders like anxiety, depression, and suicide, which negatively affect their quality of life [23-25]. Consistent with this, our study found that $10 \%, 28 \%$, and $30 \%$ of physicians reported thoughts of death or self-harming thoughts, intense anxiety, and depressive symptoms, respectively. Numerous studies had documented the intensified levels of anxiety and depression among health care professionals during the pandemic. A study stated that the prevalence rates of anxiety and depression among physicians were $25.67 \%$ and $28.13 \%$, respectively [26]. During the COVID-19 pandemic, it was reported that more than $70 \%$ of the medical staff stated intense apprehension, $25 \%$ showed anxiety, and $12 \%$ presented with depression [2]. A study conducted at the early stages of COVID-19 in China found that $50 \%$ and $45 \%$ of health care providers had depression and anxiety symptoms, respectively [27], while another study stated that $14 \%$ and $24 \%$ of the medical staff experienced depression and anxiety with COVID-19, respectively [28]. The discrepancies in 
Table 1 Association between the score of FCV-19S and physicians' demographic and clinical characteristics

\begin{tabular}{|c|c|c|c|c|c|c|}
\hline \multirow{2}{*}{$\begin{array}{l}\text { Demographic } \\
\text { variables }(N=426)\end{array}$} & \multicolumn{6}{|c|}{$\mathrm{FCV}-19 \mathrm{~S}^{\mathrm{a}}$} \\
\hline & $N$ & $\%$ & Mean & SD & $t$ test & $P$ \\
\hline \multicolumn{7}{|l|}{ Gender } \\
\hline Male & 144 & 33.8 & 18.52 & 4.97 & \multirow[t]{2}{*}{-4.692} & \multirow[t]{2}{*}{$<0.001$} \\
\hline Female & 282 & 66.2 & 20.89 & 4.91 & & \\
\hline \multicolumn{7}{|l|}{ Marital status } \\
\hline Married & 303 & 71.1 & 20.04 & 5.09 & \multirow[t]{2}{*}{0.318} & \multirow[t]{2}{*}{0.751} \\
\hline Not married & 123 & 28.9 & 20.21 & 4.96 & & \\
\hline \multicolumn{7}{|l|}{ Professional title } \\
\hline Resident & 152 & 35.7 & 20.53 & 4.93 & \multirow[t]{2}{*}{1.332} & \multirow[t]{2}{*}{0.185} \\
\hline Specialist/consultant & 274 & 64.3 & 19.85 & 5.11 & & \\
\hline \multicolumn{7}{|l|}{ Daily working hours } \\
\hline$\leq 8$ & 258 & 60.1 & 20.04 & 5.18 & \multirow[t]{2}{*}{-0.435} & \multirow[t]{2}{*}{0.664} \\
\hline$>8$ & 119 & 39.9 & 20.28 & 4.77 & & \\
\hline \multicolumn{7}{|l|}{ Working days/week } \\
\hline$\leq 5$ & 274 & 64.5 & 20.45 & 5.05 & \multirow[t]{2}{*}{1.915} & \multirow[t]{2}{*}{0.056} \\
\hline$>5$ & 152 & 35.5 & 19.47 & 5.02 & & \\
\hline \multicolumn{7}{|c|}{ Received sufficient training } \\
\hline No & 310 & 72.8 & 20.54 & 5.08 & \multirow[t]{2}{*}{3.032} & \multirow[t]{2}{*}{0.003} \\
\hline Yes & 116 & 27.2 & 18.89 & 4.79 & & \\
\hline \multicolumn{7}{|c|}{ Satisfied with hospital PPE** } \\
\hline No & 358 & 84.0 & 20.51 & 5.00 & \multirow[t]{2}{*}{3.972} & \multirow[t]{2}{*}{$<0.001$} \\
\hline Yes & 68 & 16.0 & 17.90 & 4.78 & & \\
\hline \multicolumn{7}{|l|}{ Physician's role } \\
\hline Frontline & 66 & 15.5 & 20.18 & 5.35 & -0.162 & 0.871 \\
\hline Second-line & 360 & 84.5 & 20.07 & 5.00 & & \\
\hline History of colleague affe & id-19 & & & & & \\
\hline No & 239 & 56.1 & 19.64 & 5.19 & -2.063 & 0.040 \\
\hline Yes & 187 & 43.9 & 20.66 & 4.82 & & \\
\hline History of chronic ment & & & & & & \\
\hline No & 316 & 74.2 & 19.85 & 4.86 & -1.629 & 0.104 \\
\hline Yes & 110 & 25.8 & 20.76 & 5.54 & & \\
\hline History of chronic medic & & & & & & \\
\hline No & 335 & 78.6 & 19.90 & 4.92 & -1.497 & 0.135 \\
\hline Yes & 91 & 21.4 & 20.79 & 5.48 & & \\
\hline Smoking status & & & & & & \\
\hline No & 388 & 91.1 & 20.26 & 5.04 & 2.177 & 0.030 \\
\hline Yes & 38 & 8.9 & 18.39 & 4.87 & & \\
\hline History of substance use & & & & & & \\
\hline No & 412 & 96.7 & 20.05 & 4.94 & -0.955 & 0.340 \\
\hline Yes & 14 & 3.3 & 21.36 & 7.82 & & \\
\hline History of self-harm tho & Dander & & & & & \\
\hline No & 383 & 89.9 & 19.88 & 4.98 & -2.570 & 0.011 \\
\hline Yes & 43 & 10.1 & 21.95 & 5.33 & & \\
\hline
\end{tabular}

${ }^{a}$ Fear of COVID-19 Scale. ${ }^{b}$ Personal protective equipment 


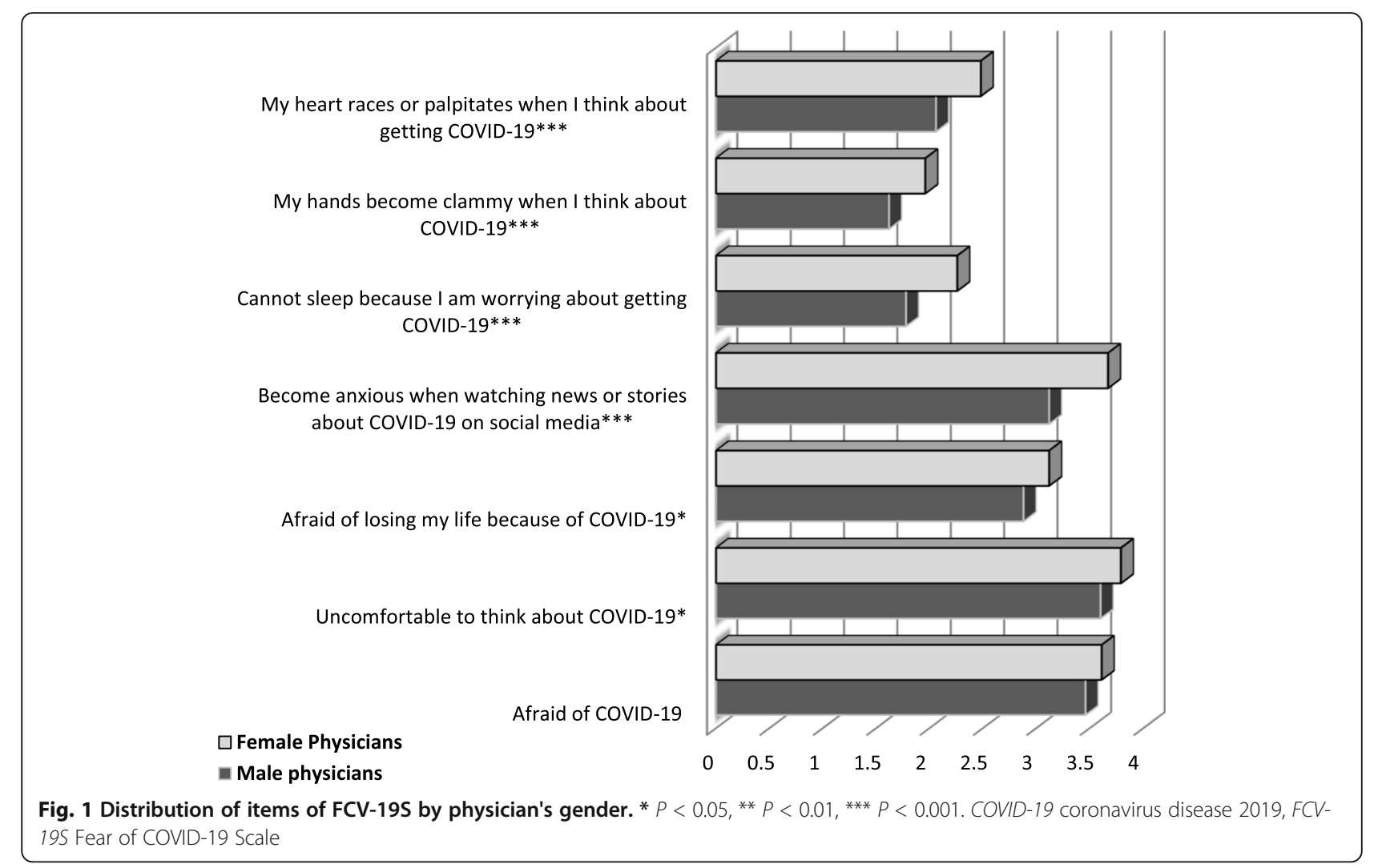

the prevalence of depression and anxiety among the studies may be related to variance in sample size, different assessment tools used, different cultural backgrounds, and different stages related to the pandemic onset.

As illustrated in Table 2, there was no significant correlation between age and coronaphobia. In line with this finding, Ahorsu et al. (2020), the founders of the FCV-19S, stated that age appeared not to affect the response pattern of the fear on the FCV-19S [14]. This study found physicians with higher levels of coronaphobia who were more likely to be females, receiving insufficient training related to the pandemic,

Table 2 Correlation between the score of FCV-19S and severity of anxiety and depressive symptoms among physicians

\begin{tabular}{|c|c|c|c|}
\hline \multirow[t]{2}{*}{$N=426$} & \multirow[b]{2}{*}{$M(S D)$} & \multicolumn{2}{|l|}{ FCV-19Sa } \\
\hline & & $\begin{array}{l}\text { Pearson correlation } \\
(r)\end{array}$ & $P$ \\
\hline Age & $\begin{array}{l}34.57 \\
(6.50)\end{array}$ & -0.084 & 0.085 \\
\hline \multicolumn{4}{|l|}{$\mathrm{HADS}^{\mathrm{b}}$} \\
\hline Total Anxiety Score & $8.05(4.01)$ & 0.588 & $\begin{array}{l}< \\
0.001\end{array}$ \\
\hline $\begin{array}{l}\text { Total Depression } \\
\text { Score }\end{array}$ & $9.07(3.27)$ & 0.465 & $\begin{array}{l}< \\
0.001\end{array}$ \\
\hline
\end{tabular}

dissatisfied with the hospital PPE, and having medical colleagues who were infected with the COVID-19 virus infection. These findings were in line with other studies which also found that females have been reported higher levels of anxiety than males [21, 26], yet, due to the self-reporting nature of most scales used for assessing anxiety, some argued male participants might have minimized symptoms [22]. Studies of previous pandemics and outbreaks also revealed that inadequate staff training [29], inadequate organizational support [30], frustration about the efficacy of precautionary measures [31], being less experienced [32], and lack of confidence in infection control and caring for affected medical colleagues during the pandemic [33] were the main variables increasing the risk of psychological distress including anxiety, depression, and stress among health care workers. Furthermore, it was claimed that severe anxiety symptoms experienced among physicians during their duty were related to their suspicion of being infected with the COVID-19 virus [1].

Integration between physical health (body) and mental health (mind) is essential to the current psychological state of physicians. In this study, the relationship between coronaphobia and the associated psychological symptoms cannot be ignored. Physicians with high levels of coronaphobia were more likely to have death wishes 
Table 3 Comparison between frontline and second-line physicians regarding their demographic and clinical characteristics

\begin{tabular}{|c|c|c|c|c|}
\hline \multirow[t]{2}{*}{$N=426$} & $\begin{array}{l}\text { Frontline } \\
(n=66)\end{array}$ & $\begin{array}{l}\text { Second-line } \\
(n=360)\end{array}$ & $t X^{2}$ & $P$ \\
\hline & \multicolumn{4}{|c|}{$N(\%), \mathrm{M}(\mathrm{SD})$} \\
\hline Age & $33.24(6.57)$ & $34.81(6.49)$ & 1.802 & 0.072 \\
\hline \multicolumn{5}{|l|}{ Gender } \\
\hline Male & $26(36.4)$ & $118(32.8)$ & 1.091 & 0.296 \\
\hline Female & $40(60.6)$ & $242(67.2)$ & & \\
\hline \multicolumn{5}{|l|}{ Marital status } \\
\hline Married & $40(60.6)$ & $263(73.1)$ & 4.209 & 0.040 \\
\hline Not married & $26(39.4)$ & $97(26.9)$ & & \\
\hline \multicolumn{5}{|l|}{ Professional title } \\
\hline Resident & $31(47.0)$ & $121(33.6)$ & 4.337 & 0.037 \\
\hline Specialist/consultant & $35(53.0)$ & $239(66.4)$ & & \\
\hline \multicolumn{5}{|l|}{ Daily working hours } \\
\hline$\leq 8$ & $37(56.1)$ & $268(75.3)$ & 10.265 & 0.001 \\
\hline$>8$ & $29(43.9)$ & $88(24.7)$ & & \\
\hline \multicolumn{5}{|l|}{ Working days/week } \\
\hline$\leq 5$ & $45(68.2)$ & $228(63.9)$ & 0.453 & 0.299 \\
\hline$>5$ & $21(31.8)$ & $129(36.1)$ & & \\
\hline \multicolumn{5}{|l|}{ Received sufficient training } \\
\hline No & $41(62.1)$ & $269(74.7)$ & 4.469 & 0.035 \\
\hline Yes & 25 (37.9) & $91(25.3)$ & & \\
\hline \multicolumn{5}{|c|}{ Satisfied with hospital PPE ${ }^{\mathrm{b}}$} \\
\hline No & $57(86.4)$ & 301 (83.6) & 0.315 & 0.362 \\
\hline Yes & $9(13.6)$ & $59(16.4)$ & & \\
\hline \multicolumn{5}{|c|}{ History of colleague affected with Covid-19 } \\
\hline No & $20(30.3)$ & $219(60.8)$ & 21.110 & $<0.001$ \\
\hline Yes & $46(69.7)$ & $141(39.2)$ & & \\
\hline \multicolumn{5}{|c|}{ History of self-harm thoughts during pandemic } \\
\hline No & $57(86.4)$ & $326(90.6)$ & 1.080 & 0.299 \\
\hline Yes & $9(13.6)$ & $34(9.4)$ & & \\
\hline $\mathrm{FCV}-19 \mathrm{~S}^{\mathrm{a}}$ & $20.18(5.35)$ & $20.07(5.00)$ & -0.162 & 0.871 \\
\hline \multicolumn{5}{|l|}{$\mathrm{HADS}^{\mathrm{C}}$} \\
\hline Total Anxiety Score & $8.67(4.31)$ & $7.93(3.67)$ & -1.260 & 0.208 \\
\hline Total Depression Score & $9.11(2.84)$ & $9.07(3.35)$ & -0.090 & 0.928 \\
\hline
\end{tabular}

${ }^{a}$ Fear of COVID- 19 scale. ${ }^{b}$ Personal protective equipment. ${ }^{c}$ Hospital Anxiety and Depression Scale

and/or self-harming thoughts as well as more anxiety and depressive symptoms. In line with our findings, excessive anxiety and fears of COVID-19 virus infection were found to be associated with suicidal thoughts and intense feelings of hopelessness [34]. Moreover, it was reported that during the pandemic, the prolonged worries would increase levels of anxiety, depression, and stress in individuals or increase the severity of the pre- existing psychiatric symptoms [35]. Similarly, the higher the scores on the fear of the COVID-19 virus scale, the higher the levels of anxiety and depressive symptoms measured by the Hospital Anxiety and Depression Scale (HADS) [14]. These replicated results might suggest that physicians with severe fear of COVID-19 might have been suffering or being at greater risk to develop these comorbid disorders. It was found that comorbid physical health conditions, history of mental health disorders, and substance use were significant risk factors of stress, depression, and anxiety among health care providers during the COVID-19 pandemic [1]. However, this study failed to find a relationship between increased scores of coronaphobia and histories of mental, medical, or substance use disorders among physicians. These findings could be rationalized as being a conservative community where mental disorders and substance use were associated with stigma, which might lead some participants to deny having mental or substance use disorders. Also, most of the participants in our study were young adults (mean age $=34.57$ years), we can argue that chronic medical diseases are not common at this age (only 21\% had a medical disease). Of interest, physicians who were smokers reported lower levels of coronaphobia in this study. It was claimed that nicotine smoking could be viewed as a remedy that acutely reduced anxiety symptoms, especially during stressful situations [36]. It also could be related that they usually have less trait anxiety, as a consequence of blunting the sympathoadrenal axis [37].

Frontline physicians are the ones currently working with COVID-19 patients. Forty-seven percent of the frontline physicians were residents, while $66.4 \%$ of the second-line physicians were specialists and consultants. In Egypt, residents of all specialties and medical officers were usually at the frontline (for example in emergency rooms). They were in direct contact and manage the patients before referral to their 2nd oncall supervisors (specialists and consultants). This would explain why most consultants were located in the second-line hospital departments.

The frontline physicians caring for COVID-19 patients, compared with their second-line counterparts, were supposed to experience higher levels of anxiety and depressive symptoms, and sleep disturbances [27]. As expected, owing to the nature of their current work duties, this study found that frontline physicians were more likely to be residents, working more than $8 \mathrm{~h}$ daily, received sufficient training related to the pandemic and have a history of medical colleague affection with COVID-19 infection when compared with their second-line counterparts. However, although the mean scores of coronaphobia, anxiety, and depressive symptoms among frontline physicians were 
higher than those of their second-line counterparts, the difference was not statistically significant. Consistent with our results, in terms of excessive fears and depressive symptoms, a recent study did not find any differences between the medical staff at the frontline areas (working in the respiratory, emergency, ICU, and infectious diseases departments) and those with lower risks of contact with COVID-19 patients (second-line medical staff working in other departments) [7]. Similarly, another study found no differences in self-rated anxiety and depressive symptoms among the staff in the COVID-19-associated department and other departments [38]. This lack of significant differences between the frontline and second-line staff was probably attributed to several reasons. First, secondline physicians might experience feelings of sympathy (towards both COVID-19 patients and frontline physicians), guilt, isolation, and apparent feeling of worthlessness due to the inability to share in the present crisis [39]. Second, with increasing admissions of COVID-19 patients and shortage of medical staff, the second-line physicians might be worried about being allocated by the government to work in the frontline areas despite being insufficiently trained or qualified to work with COVID-19 patients [40]. Third, their fears might be fueled by the floods of information from TV and media about suffering, illness, and the death of their frontline colleagues. All these feelings might in turn lead to the intensification of symptoms of fear, anxiety, and depressive symptoms among second-line physicians, and explain the absence of significant differences in the emergence of psychological symptoms when compared with their frontline counterparts.

The results of the current study should be interpreted in the context of its limitations. First, because of the disease outbreak, we were unable to conduct face-to-face interviews, instead, depended on selfrating scales with response bias, so these scales only provided a preliminary screening; thus, further confirmation and intervention were warranted. Second, the selection of participants from Sharkia Province, despite being one of the largest provinces in Egypt, would limit the generalization of our findings. Third, being a cross-sectional study might limit the causeeffect relationship. So, further future longitudinal studies are needed. In addition, it was difficult during the pandemic to include a control group of nonmedical personnel. Although these limitations were present, to our knowledge, this study would be the first in Egypt and the Middle East to assess the psychological impact of the COVID-19 virus infection among physicians using a new specific assessment tool for evaluating the corona virus-related fears.

\section{Conclusions}

During the COVID-19 pandemic, physicians had higher rates of coronaphobia which in turn might lead to or intensify anxiety and depressive symptoms among them; however, frontline physicians were not significantly different from second-line physicians regarding rates of these symptoms. Female gender, receiving insufficient training related to the pandemic, dissatisfaction with the hospital PPE measures, and having a colleague affected with COVID-19 infection were significant risk factors for coronaphobia among physicians. Protecting health care providers is a central component of public health policy during the COVID-19 pandemic. Routine mental and physical assessment of medical personnel involved in diagnosing and treating patients with COVID-19 should be guaranteed, and special interventions to promote their mental well-being, when affected, need to be implemented.

\begin{abstract}
Abbreviations
COVID-19: Coronavirus disease; FCV-19S: Fear of COVID-19 scale; HADS: Hospital anxiety and depression scale; PPE: Personal protective equipment; SARS-Cov-2: Severe acute respiratory syndrome coronavirus 2
\end{abstract}

\section{Acknowledgments}

We would like to thank all the physicians, who actively participated in this study, for their time and effort.

\begin{abstract}
Authors' contributions
MA was responsible for the work design and writing. MS helped in interpretation of data, formal analysis, and editing. HE contributed in writing, revising the manuscript, and editing. EF was responsible for the process of general editing and final revision. The authors have read and approved the manuscript.
\end{abstract}

\section{Funding}

None

Availability of data and materials

All datasets, generated or analyzed in this study, are available from the corresponding author upon reasonable request.

\section{Declarations}

Ethics approval and consent to participate

The present study protocol had been approved by the Zagazig University institutional review board (IRB) (no. 6216-5-7-2020). The study procedures were following the ethical guidelines outlined in the Declaration of Helsinki and its later amendments. All participants had signed written informed consent after discussing the study objectives and confirming confidentiality.

Consent for publication

Not applicable

Competing interests

All authors declared that they had no competing interests.

\section{Author details}

${ }^{1}$ Psychiatry Department, Faculty of Medicine, Zagazig University, Zagazig, Egypt. ${ }^{2}$ 2015-2016 Hubert H. Humphrey Fellowship, Department of Psychology, Virginia Commonwealth University, Richmond, USA. 
Received: 18 March 2021 Accepted: 13 July 2021

Published online: 29 July 2021

\section{References}

1. Zhu Z, Xu S, Wang H, Liu Z, Wu J, Li G, et al. COVID-19 in Wuhan: Sociodemographic characteristics and hospital support measures associated with the immediate psychological impact on healthcare workers. EClinicalMedicine. 2020;24:100443 https://doi.org/10.1016/j.eclinm.2020.1 00443.

2. Liu C-Y, Yang Y-Z, Zhang X-M, Xu X, Dou Q-L, Zhang W-W, et al. The prevalence and influencing factors in anxiety in medical workers fighting COVID-19 in China: a cross-sectional survey. Epidemiol Infect. 2020;48:e98 https:/doi.org/10.1017/S0950268820001107.

3. Galea S, Merchant RM, Lurie N. The mental health consequences of COVID19 and physical distancing. The need for prevention and early intervention. JAMA Intern Med. 2020;180:817-8 https://doi.org/10.1001/jamainternmed.2 020.1562 .

4. Holmes EA, O'Connor RC, Perry VH, Tracey I, Wessely S, Arseneault L, Ballard C, Christensen H, Cohen Silver R, Everall I, Ford T, John A, Kabir T, King K Madan I, Michie S, Przybylski AK, Shafran R, Sweeney A, Worthman CM, Yardley L, Cowan K, Cope C, Hotopf M, Bullmore E. Multidisciplinary research priorities for the COVID-19 pandemic: a call for action for mental health science. Lancet Psychiatry 2020; 7:547-60. https://doi.org/10.1016/S221 5-0366

5. Roy D, Tripathy S, Kar SK, Sharma N, Verma SK, Kaushal V. Study of knowledge, attitude, anxiety \& perceived mental healthcare need in Indian population during COVID-19 pandemic. Asian J Psychiatr. 2020;51:102083102083. https://doi.org/10.1016/j.ajp.2020.102083.

6. Kang L, Li Y, Hu S, Chen M, Yang C, Yang BX, et al. The mental health of medical workers in Wuhan, China dealing with the 2019 novel coronavirus. Lancet Psychiatry. 2020;7:14.https://doi.org/10.1016/S2215-0366(20)30047-X.

7. Lu W, Wang H, Lin Y and Li L. Psychological status of medical workforce during the COVID-19 pandemic: a cross-sectional study. Psychiatry Res. 2020;288:112936. https://doi.org/10.1016/j.psychres.2020.112936.

8. Alyami M, Henning M, Krägeloh CU and Alyami H. Psychometric evaluation of the Arabic version of the Fear of COVID-19 Scale. Int J Ment Heal Addict. 2020. https://doi.org/10.1007/s11469-020-00316-x.

9. Zarghami M. Psychiatric aspects of coronavirus (2019-nCoV) infection. Iran J Psychiatry Behav Sci. 2020;14:e102957. https://doi.org/10.5812/ijpbs.102957.

10. Asmundson GJG, Taylor S. Coronaphobia: fear and the 2019-nCoV outbreak. J Anxiety Disord. 2020;70:102196 https://doi.org/10.1016/j.janxdis.2020.102196.

11. Tempest EL, Flooding ENSo, Group HS, Carter B, Beck CR and Rubin GJ. Secondary stressors are associated with probable psychological morbidity after flooding: a cross-sectional analysis. Eur J Pub Health. 2017:27:1042-7. https://doi.org/10.1093/eurpub/ckx182.

12. Deans AG, Deans JA, Burton AH, Dicker RC. Epi-Info version 6: a wordprocessing, database, and statistics program for epidemiology on microcomputers. Centers for Disease Control and Prevention; 1994.

13. CAPMAS Number of doctors in Governmental Sector: Annual Bulletin of Health Services. The central agency for public mobilization and statistics. 2019. https://www.capmas.gov.eg/Pages/IndicatorsPage.aspx?Ind_id=1064

14. Ahorsu DK, Lin C-Y, Imani V, Saffari M, Griffiths MD and Pakpour AH. The Fear of COVID-19 Scale: development and initial validation. Int J Ment Heal Addict. 2020;1-9. https://doi.org/10.1007/s11469-020-00270-8.

15. Nikopoulou VA, Holeva V, Parlapani EP, Karamouzi P, Voitsidi GN. Porfyr et al. Mental health screening for COVID-19: a proposed cutoff score for the Greek version of the Fear of COVID-19 Scale (FCV-19S). Int J Ment Heal Addict. 2020; https://doi.org/10.1007/s11469-020-00414-w.

16. Zigmond AS and Snaith RP. The hospital anxiety and depression scale. Acta Psychiatr Scand. 1983;67(6):361-370. https://doi.org/10.1111/j.1600-0447.1 983.tb09716.x

17. El-Rufaie OEFA and Absood G. Validity study of the Hospital Anxiety and Depression Scale among a group of Saudi patients. Br J Psychiatry. 1987; 151(5):687-8. https://doi.org/10.1192/bjp.151.5.687.

18. Statistical package for the social sciences Version 20.0. Chicago: SPSS Inc; 2011.

19. Amin S. The psychology of coronavirus fear: are healthcare professionals suffering from corona-phobia? Int J Healthc Manag. 2020;13(3):249-56. https://doi.org/10.1080/20479700.2020.1765119/.

20. Mohindra R, Ravaki R, Suri V, Bhalla A and Singh SM. Issues relevant to mental health promotion in frontline health care providers managing quarantined/isolated COVID19 patients. Asian J Psychiatr. 2020;51:102084. https://doi.org/10.1016/j.ajp.2020.102084.

21. Kang L, Ma S, Chen M, Yang J, Wang Y, Li R, Yao L, Bai H, Cai Z, Xiang Yang B, Hu S, Zhang K, Wang G, Ma C, Liu Z Impact on mental health and perceptions of psychological care among medical and nursing staff in Wuhan during the 2019 novel coronavirus disease outbreak: a crosssectional study. Brain Behav Immun. 2020;87:11-17. https://doi.org/10.1016/j. bbi.2020.03.028.

22. Huang JZ, Han MF, Luo TD, Ren AK and Zhou XP. Mental health survey of medical staff in a tertiary infectious disease hospital for COVID-19. Zhonghua Lao Dong Wei Sheng Zhi Ye Bing Za Zhi. 2020;38:192-5. https:// doi.org/10.3760/cma.j.cn121094-20200219-00063.

23. Malta M, Rimoin AW, Strathdee SA. The coronavirus 2019-nCoV epidemic: is hindsight 20/20? EClinical Medicine. 2020;20:100289. https://doi.org/10.1016/ j.eclinm.2020.10028

24. Abdelghani M, El-Gohary HM, Fouad E, Merva H. Addressing the relationship between perceived fear of COVID-19 virus infection and emergence of burnout symptoms in a sample of Egyptian physicians during COVID-19 pandemic: a cross-sectional study. MECP. 2020;27:70. https://doi.org/10.11 86/s43045-020-00079-0.

25. Abdelghani M, Mahdy R, El-Gohari H. Health anxiety to COVID-19 virus infection and its relationship to quality of life in a sample of health care workers in Egypt: a cross-sectional study. Arch Psychiatry Psychother. 2020; 23(1):19-28. https://doi.org/10.12740/APP/130304.

26. Gong Y, Han T, Chen W, Dib HH, Yang G, Zhuang R, Chen Y, Tong X, Yin X, Lu Z Prevalence of anxiety and depressive symptoms and related risk factors among physicians in China: a cross-sectional study. PLoS One.2020; 9(7):e103242. https://doi.org/10.1371/journal.pone.0103242.

27. Lai J, Ma S, Wang Y, Cai Z, Hu J, Wei N, Wu J, du H, Chen T, Li R, Tan H, Kang L, Yao L, Huang M, Wang H, Wang G, Liu Z, Hu S. Factors associated with mental health outcomes among health care workers exposed to coronavirus disease 2019. JAMA Netw Open. 2020;3(3):e203976. https://doi. org/10.1001/jamanetworkopen.2020.3976.

28. Zhu Z, Xu S, Wang H, Liu Z, Wu J, Li G, et al. COVID-19 in Wuhan: immediate psychological impact on 5062 health workers. MedRxiv. 2020;02. 20.2 0025338. https://doi.org/10.1016/j.eclinm.2020.100443.

29. Maunder RG, Lancee WJ, Balderson KE, Bennett JP, Borgundvaag B, Evans S, Fernandes C, Goldbloom D, Gupta M, Hunter J, McGillis Hall L, Nagle L, Pain C, Peczeniuk S, Raymond G, Read N, Rourke S, Steinberg R, Stewart T, VanDeVelde-Coke S, Veldhorst G, Wasylenki D. Long-term psychological and occupational effects of providing hospital healthcare during SARS outbreak. Emerg Infect Dis. 2020;2(12):1924-32. https://doi.org/10.3201/eid1212. 060584.

30. Maunder RG, Lancee WJ, Rourke S, Hunter JJ, Goldbloom D, Balderson K, Petryshen P, Steinberg R, Wasylenki D, Koh D, Fones CSL. Factors associated with the psychological impact of severe acute respiratory syndrome on nurses and other hospital workers in Toronto. Psychosom Med. 2004;66(6): 938942. https://doi.org/10.1097/01.psy.0000145673.84698.18.

31. Nickell LA, Crighton EJ, Tracy CS, Al-Enazy H, Bolaji Y, Hanjrah S, et al. Psychosocial effects of SARS on hospital staff: survey of a large tertiary care institution. CMAJ. 2004;170(5):793-8. https://doi.org/10.1503/cmaj.1031077.

32. Lancee WJ, Maunder RG, Goldbloom DS and Coauthors for the Impact of SS. Prevalence of psychiatric disorders among Toronto hospital workers one to two years after the SARS outbreak. Psychiatr Serv. 2008;59:915. https://doi. org/10.1176/ps.2008.59.1.91.

33. Chua SE, Cheung V, Cheung C, MCAlonan GM, Wong JWS, Cheung EPT, et al. Psychological effects of the SARS outbreak in Hong Kong on high-risk health care workers. Can J Psychiatr. 2004;49:391-3. https://doi.org/10.1177/ 070674370404900609

34. Lee SA, Mathis AA, Jobe MC and Pappalardo EA. Clinically significant fear and anxiety of COVID-19: a psychometric examination of the Coronavirus Anxiety Scale. Psychiatry Res. 2020;290:112-3. https://doi.org/10.1016/j. psychres.2020.113112.

35. Shigemura J, Ursano RJ, Morganstein JC, Kurosawa M, Benedek DM. Public responses to the novel 2019 coronavirus (2019-nCoV) in Japan: mental health consequences and target populations. Psychiatry Clin Neurosci. 2020; 74:281-2. https://doi.org/10.1111/pcn.12988.

36. Leventhal AM and Zvolensky MJ. Anxiety, depression, and cigarette smoking: a transdiagnostic vulnerability framework to understanding emotion-smoking comorbidity. Psychol Bull. 2015;141:176-212. https://doi. org/10.1037/bul0000003. 
37. Wiggert N, Wilhelm FH, Nakajima M, al'Absi M. Chronic smoking, trait anxiety, and the physiological response to stress. Subst Use Misuse. 2016; 51(12):1619-28. https://doi.org/10.1080/10826084.2016.1191511.

38. Liang $Y$, Chen $M$, Zheng $X$ and Liu J. Screening for Chinese medical staff mental health by SDS and SAS during the outbreak of COVID-19. J Psychosom Res. 2020;133:102-10. https://doi.org/10.1016/j.jpsychores.202 0.110102 .

39. Gautam M, Kaur M, Mahr G. COVID-19-associated psychiatric symptoms in health care workers: viewpoint from Internal Medicine and Psychiatry residents. Psychosomatics.2020;61 (5):579-81. https://doi.org/10.1016/j.psym.2 020.04.009.

40. Li Z, Ge J, Yang M, Feng J, Qiao M, Jiang R, Bi J, Zhan G, Xu X, Wang L, Zhou Q, Zhou C, Pan Y, Liu S, Zhang H, Yang J, Zhu B, Hu Y, Hashimoto K, Jia Y, Wang H, Wang R, Liu C, Yang C. Vicarious traumatization in the general public, members, and non-members of medical teams aiding in COVID-19 control. Brain Behav Immun. 2020;88(20):916-9. https://doi.org/1 0.1016/j.bbi.2020.03.007.

\section{Publisher's Note}

Springer Nature remains neutral with regard to jurisdictional claims in published maps and institutional affiliations.

\section{Submit your manuscript to a SpringerOpen ${ }^{\circ}$ journal and benefit from:}

- Convenient online submission

- Rigorous peer review

- Open access: articles freely available online

- High visibility within the field

- Retaining the copyright to your article

Submit your next manuscript at $\boldsymbol{\nabla}$ springeropen.com 